\title{
Morphometric growth characteristics and body composition of bullfrog tadpoles in captivity
}

\section{Características do crescimento morfométrico e composição corporal de girinos de rã-touro em cativeiro}

\author{
Cleber Fernando Menegasso Mansano ${ }^{1 *}$; Marta Verardino De Stéfani²; \\ Marcelo Maia Pereira ${ }^{1}$; Thálita Stefann Ribeiro Nascimento ${ }^{1}$; \\ Beatrice Ingrid Macente ${ }^{3}$
}

\begin{abstract}
Feed management needs to be improved in frog farming to reduce the indirect effects of inadequate feeding and, consequently, to increase growth rates and nutrient deposition, obtaining better quality animals. The objective of this study was to establish morphometric growth curves for bullfrog tadpoles (Lithobates catesbeianus) and to determine nutrient deposition in the carcass. A total of 6,480 bullfrogs (Gosner stage 25) received an experimental diet (26.23\% digestible protein and 32.68\% crude protein) and a commercial diet (37.92\% crude protein) ad libitum. A Gompertz model was used to describe the growth curve. Tadpoles fed the experimental diet presented higher final protein deposition. In addition, the sigmoidal curve was much more homogenous, indicating a more constant daily protein deposition rate. The Gompertz model provided an excellent fit of the data to describe the morphometric growth curve and carcass nutrient deposition of bullfrog tadpoles, showing that animals fed the experimental diet presented a better growth rate and nutrient deposition.
\end{abstract}

Key words: Frog farming, Gompertz model, growth curve, nutrient deposition

\section{Resumo}

Melhorias no manejo alimentar devem ser implementadas na ranicultura, visando diminuir os efeitos indiretos da alimentação inadequada, resultando em melhores taxas de crescimento e deposição de nutrientes, consequentemente obtendo animais de melhor qualidade. O objetivo foi estabelecer curvas de crescimento morfométrico de girinos de rã-touro e sua deposição de nutrientes na carcaça. Foram utilizados 6.480 girinos de rã-touro no estágio 25 de Gosner, alimentados com dieta experimental (26,23\% PD e $32,68 \%$ PB) e comercial (37,92\% PB), oferecida ad libitum. O modelo utilizado para descrever a curva de crescimento foi de Gompertz. Os girinos alimentados com a dieta experimental, além de apresentarem uma deposição protéica final maior, o modelo sigmoidal apresentou-se muito mais homogêneo, mostrando uma taxa de deposição protéica diária mais constante. $\mathrm{O}$ modelo de Gompertz apresentou um ótimo ajuste para descrição da curva de crescimento morfométrico e deposição de nutrientes na carcaça para girinos de rã-touro, mostrando que os girinos alimentados com a dieta experimental, apresentaram melhor taxa de crescimento e deposição de nutrientes na carcaça.

Palavras-chave: Ranicultura, modelo de Gompertz, curva de crescimento, deposição de nutrientes

\footnotetext{
${ }^{1}$ Discentes do Curso de Doutorado em Aquicultura, Centro de Aquicultura, Universidade Estadual Paulista, UNESP, Jaboticabal, SP, Brasil. E-mail: clebermansano@yahoo.com.br; mmaiap2001@yahoo.com.br; thalitazoo@hotmail.com

${ }^{2}$ Prof $^{\mathrm{a}} \mathrm{Dr}^{\mathrm{a}}$, Centro de Aquicultura, Pós-Graduação em Aquicultura, UNESP, Jaboticabal, SP, Brasil. E-mail: martavs@fcav.unesp.br

${ }^{3}$ Discente do Curso de Doutorado em Medicina Veterinária, Faculdade de Ciências Agrárias e Veterinárias, Dept ${ }^{\circ}$ de Medicina Veterinária Preventiva e Reprodução Animal, UNESP, Jaboticabal, SP, Brasil. E-mail: beatrice.vetuel@yahoo.com.br

* Author for correspondence
} 


\section{Introduction}

The bullfrogs (Lithobates catesbeianus) present a complex life cycle (SIMMONS; COSTA; GERSTEIN, 2004; ROBERTS et al., 2009). The first stage (tadpole stage) is essential for good functioning of the frog farm since the animals that emerge after metamorphosis will determine the conditions for frog culture. In this respect, an adequate diet is fundamental for frog rearing since mortality or abnormal development are classical signs of possible nutritional disorders (SEIXAS FILHO et al., 2008).

There are several studies designed to improve frog feeding and nutrition, but most of them only investigated the need for crude protein and energy (CARMONA-OSALDE et al., 1996; SEIXAS FILHO et al., 1998; BARBOSA; SILVEIRA; GOMIDE, 2005). The digestibility of protein and energy of some tadpole dietary components has also been evaluated (ALBINATI et al., 2000; SECCO; STÉFANI; VIDOTTI, 2005). However, the nutritional requirements of tadpoles remain unknown. Because of the lack of these data, diets of other species with different nutritional requirements, such as carnivorous fish, are generally administered to tadpoles (SEIXAS FILHO et al., 2008).

Studies developing growth models, taking into account the information provided by them, are important to implement feeding and genetic breeding programs, which are scarce in frog farming (SANTOS et al., 2007; MARCATO et al., 2010). Non-linear mathematical models describe the growth characteristics of individuals based on the response profile of some parameters over time, thus permitting to identify, for example, heavier animals at a younger age (MARCATO et al., 2010; SILVA et al., 2011). Non-linear models have been described for various domestic animals, such as commercial chicken ( MARCATO et al., 2008), Santa Ines sheep (SARMENTO et al., 2006), beef cows (SILVA et al., 2011), Nile tilapia (SANTOS et al., 2007), postmetamorphic pepper frog
(AGOSTINHO et al., 1991) and postmetamorphic bullfrog (RODRIGUES et al., 2007), and have been shown to model the growth of these species with statistical accuracy. This tool has also been adopted to determine the nutritional requirements of animals since it contributes to define the ideal time necessary to reach maximum weight (WAFA; PIERRE; DANIEL, 2004). Non-linear models may therefore contribute to the development of a feeding program for bullfrog tadpoles designed to produce large numbers of high-quality froglets, which are of fundamental importance for frog farming (BARBOSA; SILVEIRA; GOMIDE, 2005).

The objective of the present study is to determine the growth curves and rates, as well as the carcass nutrient deposition (protein, fat, minerals, and water), of bullfrog tadpoles using a non-linear Gompertz model.

\section{Material and Methods}

The experiment was conducted at the Laboratory of Aquatic Organism Nutrition, Aquaculture Center, São Paulo State University (UNESP), Jaboticabal, Brazil, between November 2010 and January 2011 (64 days).

\section{Animals and experimental conditions}

A total of 6,480 bullfrog tadpoles (Lithobates catesbeianus) in stage 25 (GOSNER, 1960) of the same spawn, with an initial weight of $0.044 \pm 0,001 \mathrm{~g}$, were obtained from the frog farm of the Aquaculture Center, UNESP. A completely randomized design with two treatments (experimental and commercial diet) and six repetitions was used, in which each experimental repetition consisted of three tanks. The animals were housed in thirty-six $100-\mathrm{L}$ amiantus tanks containing $90 \mathrm{~L}$ of water at an initial density of 2 tadpoles/L. The tanks were supplied individually and drained directly through the bottom. The water obtained from a mine was chlorine free and was changed $100 \%$ at intervals of 
$24 \mathrm{~h}$ to prevent interferences with the feeding of the animals. Water flow was controlled (SCHMIDT; KNOWLES; SIMMONS, 2011).

For the maintenance of water quality, the tanks were siphoned out on alternate days to remove feces and uneaten food. The maximum and minimum temperatures of the environment and of the tank water were measured daily with a digital thermometer (Incoterm). Dissolved oxygen (YSI Professional Oxygen Meter), conductivity (PHTEK
Pocket Conductivity Meter, model CD-203), and pH (PHTEK Pocket pH Meter, model pH-100) were measured weekly.

\section{Diets and feed management}

The tadpoles were fed two ground diets: an experimental diet containing 26.23\% digestible protein $(32.68 \%$ crude protein) (Table 1) and a commercial diet containing $37.92 \%$ crude protein (Table 2).

Table 1. Formula and nutritional composition of the experimental diet.

\begin{tabular}{lc}
\hline Ingredient & $\left(\mathrm{g} \cdot \mathrm{kg}^{-1}\right)$ \\
\hline Fish meal & 180.0 \\
Soybean meal & 205.0 \\
Poultry by- product meal & 100.0 \\
Wheat meal & 170.0 \\
Corn meal & 178.8 \\
Corn Starch & 100.0 \\
Soybean oil & 60.0 \\
Mineral and vitamin premix $*$ & 6.0 \\
BHT & 0.2 \\
\hline Composition & \\
\hline Crude protein $\left(\mathrm{g}^{-\mathrm{kg}^{-1}}\right)$ & 326.8 \\
Digestible protein ${ }^{2}\left(\mathrm{~g} \cdot \mathrm{kg}^{-1}\right)$ & 262.3 \\
Gross energy $\left(\mathrm{kcal}^{\mathrm{kg}}\right)$ & 4434.34 \\
Digestible energy $\left(\mathrm{kcal} / \mathrm{kg}^{*} * *\right.$ & 3743.07 \\
Crude fiber $\left(\mathrm{g} \cdot \mathrm{kg}^{-1}\right)$ & 24.5 \\
Mineral matter $\left(\mathrm{g} \cdot \mathrm{kg}^{-1}\right)$ & 77.8 \\
Ether extract $\left(\mathrm{g} \cdot \mathrm{kg}^{-1}\right)$ & 109.8 \\
Nitrogen-free extract $\left(\mathrm{g} \cdot \mathrm{kg}^{-1}\right)$ & 381.3 \\
\hline
\end{tabular}

* Moisture content: 20.0 g.kg-1; ashes: 716.442 g.kg-1; choline: 30,000 mg. $\mathrm{kg}^{-1}$; magnesium: 0.0085\%; sulfur: 1.1589\%; iron: 25,714 mg.kg-1 ${ }^{-1}$ copper: 1,960 mg.kg- ${ }^{1}$; manganese: $13,345 \mathrm{mg} \cdot \mathrm{kg}_{-}{ }^{1}$; zinc: $30,000 \mathrm{mg} \cdot \mathrm{kg}^{-1}$; iodine: $939 \mathrm{mg} \cdot \mathrm{kg}^{-1}$; selenium: 30 mg.kg-1; vitamin A: 600,000 IU. $\mathrm{kg}^{-1}$; vitamin D3: 600,000 IU. $\mathrm{kg}^{-1}$; vitamin E: 12,000 mg. $\mathrm{kg}^{-1}$; vitamin K3: $631 \mathrm{mg} . \mathrm{kg}^{-1}$; thiamine (vitamin B1): 1,176 mg.kg-1; riboflavin (vitamin B2): 1,536 mg. $\mathrm{kg}^{-1}$; pyridoxine (vitamin B6): 1,274 mg. $\mathrm{kg}^{-1} ;$ vitamin B12: 4,000 $\mu \mathrm{g} . \mathrm{kg}^{-1}$; niacin: 19,800 mg. $\mathrm{kg}^{-1}$; pantothenic acid (vitamin B3): 3,920 mg.kg ${ }^{-1}$; folic acid: 192 mg. $\mathrm{kg}^{-1}$; biotin: 20 mg.kg-1; vitamin C: 40,250 mg. $\mathrm{kg}^{-1}$.

** Values calculated based on the digestibility coefficient proposed by Secco, Stéfani and Vidotti (2005).

Source: Elaboration of the authors.

Bromatological analysis of the components of the experimental diet was performed at the Laboratory of Aquatic Organism Nutrition,
Aquaculture Center, UNESP, and at the Laboratory of Animal Nutrition, Department of Animal Sciences, FCAV, UNESP. 
Table 2. Centesimal composition analyzed of the commercial diet.

\begin{tabular}{lc}
\hline & Centesimal composition \\
\hline Crude protein $\left(\mathrm{g} \cdot \mathrm{kg}^{-1}\right)$ & 379.2 \\
Ether extract $\left(\mathrm{g} \cdot \mathrm{kg}^{-1}\right)$ & 75.3 \\
Cross energy $(\mathrm{kcal} / \mathrm{kg})$ & 4156.34 \\
Crude fiber $\left(\mathrm{g} \cdot \mathrm{kg}^{-1}\right)$ & 33.5 \\
Mineral matter $\left(\mathrm{g} \cdot \mathrm{kg}^{-1}\right)$ & 109.5 \\
\hline
\end{tabular}

Basic diet composition: ground whole corn, soybean meal, corn gluten meal - 60, meat and bone meal, hydrolyzed feather meal, blood meal, stabilized vegetable fat, sodium chloride (common salt), choline chloride, and limestone. Eventual substitutes: ground whole grain sorghum, broken rice, corn meal, corn gluten meal, wheat bran, rice bran, and dry sugar cane yeast. Premix (minimum): Vitamin A (min) 35,000 IU; vitamin D3 (min) 2,000 IU; vitamin E (min) $120 \mathrm{IU}$; vitamin K3 (min) $800 \mathrm{mg}$; folic acid (min) $10 \mathrm{mg}$; biotin (min) $10 \mathrm{mg}$; thiamine (B1) (min) $25 \mathrm{mg}$; riboflavin (B2) (min) $35 \mathrm{mg}$; pyridoxine (B6) (min) $40 \mathrm{mg}$; vitamin 12 (min) $100 \mu \mathrm{g}$; niacin (min) 350 $\mathrm{mg}$; pantothenic acid ( $\mathrm{min}) 150 \mathrm{mg}$; choline $(\mathrm{min}) 2,500 \mathrm{mg}$; copper (min) $25 \mathrm{mg}$; iron (min) $150 \mathrm{mg}$; manganese (min) $75 \mathrm{mg}$; selenium (min) $1 \mathrm{mg}$; zinc (min) $140 \mathrm{mg}$; mannan oligosaccharide (min) $60 \mathrm{mg}$.

Source: Elaboration of the authors.

The animals were fed ad libitum three times per day, avoiding leftovers in such a way the quantity supplied corresponded to the quantity consumed (SOLOMON; TARUWA, 2011).

\section{Variables analyzed}

For the calculation of mean weight and weight gain (final weight - initial weight), 10\% of the tadpoles of each experimental tank were randomly selected and weighed individually on a digital electronic balance to the nearest $0.01 \mathrm{~g}$. In addition, the total length (from snout to tail tip) and partial length (snout to tail base) of the tadpoles were measured with a digital caliper. These measurements were obtained on days 1, 13, $23,33,42,55$ and 64 , last day of the experiment and onset of metamorphic climax (WRIGHT; RICHARDSON; BIGOS, 2011).
Food intake in each experimental tank was quantified by the calculation of apparent feed conversion (food intake/weight gain). Before transfer to the experimental tanks, a batch of tadpoles ( $\pm 35 \mathrm{~g}$ live weight tadpoles) was killed for the analysis of initial body composition (protein crude, ether extract, dry matter, and ash). In the subsequent evaluations (days 13, 23, 33, 42, 55 and 64), samples of $10 \mathrm{~g}$ live weight tadpoles were collected from each of three experimental tanks, corresponding to an experimental repetition. The tadpoles selected from the three tanks were transferred to a container with water for $24 \mathrm{~h}$ for the elimination of gastrointestinal tract content. Next, the animals were placed on ice for stunning, killed, stored in a plastic container, and frozen for subsequent processing and preparation of laboratory samples.

\section{Sample processing and laboratory analysis}

For analysis of carcass nutrients, the frozen tadpoles were ground in a food processor to obtain homogenous samples. The samples were then transferred to disposable plastic Petri dishes and lyophilized at $-50^{\circ} \mathrm{C}$ in a Thermo VLP200 lyophilizer to obtain pre-dried material. Next, the samples were ground in a ball mill and sent to the laboratory for analysis of protein (ETHERIDGE; PESTI; FOSTER, 1998), ether extract, dry matter, and ash (SILVA; QUEIROZ, 2002).

\section{Estimation of the growth curve and statistical analysis}

A Gompertz model was used to describe the growth curve and body composition (MANSANO et al., 2012), (protein crude, fat, water, and ash) of bullfrog tadpoles: $\mathrm{Wt}=\mathrm{Wm} \times \exp \times(-\exp \times$ $\left.\left(-\mathrm{b} \times\left(\mathrm{t}-\mathrm{t}^{*}\right)\right)\right)$, where $\mathrm{Wt}=$ nutrient weight $(\mathrm{g})$ 
of the animal at time $t$, expressed as a function of $\mathrm{Wm} ; \mathrm{Wm}=$ nutrient weight $(\mathrm{g})$ at maturity of the animal; $b=$ maturation rate (per day); $t^{*}=$ time (days) when the growth rate is maximal. On the basis of the estimated equation, growth rates $(\mathrm{g} /$ day) were calculated as a function of time $(\mathrm{t})$ by the derivative $\mathrm{dWt} / \mathrm{dt}=\mathrm{b}$. Wt . exp . $(-\mathrm{b}$. $(\mathrm{t}-$ $\left.t^{*}\right)$ ) of the equation described by Winsor (1932). When the parameters were adjusted, we used the NLIN procedure of SAS (2001), and the parameter estimates were obtained by iterative modified Gauss-Newton method, developed by Hartley (1961), for non-linear models.

The parameters indicated in the equations of the non-linear mathematical models and feed conversion (observed and estimated) were submitted to $F$ test using procedure of the SAS software (2001).

The experimental procedures were conducted in accordance with the guidelines of the Brazilian College of Animal Experimentation (COBEA) and were approved by the Ethics Committee on Animal Use of São Paulo State University (protocol $n^{\circ}$ 025000/10).

\section{Results}

Physical and chemical characteristics of the water

The minimum and maximum temperatures of the tank water during the experiment were $24.2 \pm$
1.4 and $26.0 \pm 1.2^{\circ} \mathrm{C}$, respectively.

The mean dissolved oxygen content of the water was $3.07 \pm 0.92 \mathrm{mg} . \mathrm{L}^{-1}$, the electrical conductivity of the tank water was $38 \pm 0.26 \mu \mathrm{S} / \mathrm{cm}$ and the mean $\mathrm{pH}$ of the tank water was $6.17 \pm 0.34$.

\section{Growth}

Table 3 shows the parameter estimates obtained with the Gompertz equation for live weight, total length, partial length, food intake, protein intake, and body composition (protein, water, fat, and ashes) of tadpoles fed the different diets.

Tadpoles fed the experimental diet reached a higher final live weight estimated with the Gompertz equation than those receiving the commercial diet (Table 3). However, these differences in live weight were not as marked at the beginning of the experiment, becoming more prominent after day 23 (Figure 1A).

Tadpoles fed the experimental diet (26.23\% digestible protein and $32.68 \%$ crude protein) presented better daily weight gain (Figure 2A).

The total length of bullfrog tadpoles was not influenced either diet (Table 3 and Figure 1B). In contrast, there was a significant difference in partial length, with the best result being obtained for animals fed the experimental diet which also presented a higher final live weight (Table 3 and Figure 1C). 
Table 3. Parameter estimates obtained with the Gompertz equation for live weight, food and protein intake, total and partial lengths and nutrient deposition of bullfrog tadpoles fed the experimental (ED) and commercial (CD) diets.

\begin{tabular}{|c|c|c|c|c|}
\hline \multirow{2}{*}{ Variable } & \multirow{2}{*}{ Diet } & \multicolumn{3}{|c|}{ Parameter } \\
\hline & & $\mathrm{Pm}$ & b (per day) & $\mathrm{t}^{*}$ \\
\hline \multirow{2}{*}{ Live weight (g) } & $\mathrm{ED}$ & $10.66 \pm 1.0517 \mathrm{a}$ & $0.0558 \pm 0.0088$ & $38.195 \pm 2.2956$ \\
\hline & $\mathrm{CD}$ & $9.54 \pm 0.4174 b$ & $0.0590 \pm 0.0044$ & $37.571 \pm 0.9918$ \\
\hline$P$ value & & 0.0028 & 0.3628 & 0.3020 \\
\hline \multirow{2}{*}{ Total length (mm) } & ED & $120.0 \pm 3.8715$ & $0.0394 \pm 0.0022$ & $21.813 \pm 1.0297$ \\
\hline & $\mathrm{CD}$ & $122.1 \pm 3.1691$ & $0.0371 \pm 0.0016$ & $23.516 \pm 0.8630$ \\
\hline$P$ value & & 0.3124 & 0.2764 & 0.1046 \\
\hline \multirow{2}{*}{ Partial length (mm) } & ED & $37.26 \pm 1.0098 \mathrm{a}$ & $0.0415 \pm 0.0023$ & $16.465 \pm 0.8371$ \\
\hline & $\mathrm{CD}$ & $35.56 \pm 0.8304 b$ & $0.0425 \pm 0.0021$ & $15.978 \pm 0.7135$ \\
\hline$P$ value & & 0.0199 & 0.5618 & 0.4519 \\
\hline \multirow{2}{*}{ Cumulative food intake (g) } & ED & $15.19 \pm 0.6551$ & $0.0482 \pm 0.0026$ & $42.563 \pm 1.0919$ \\
\hline & $\mathrm{CD}$ & $15.33 \pm 0.5732$ & $0.0485 \pm 0.0023$ & $42.656 \pm 0.9413$ \\
\hline$P$ value & & 0.5828 & 0.7863 & 0.5979 \\
\hline \multirow{2}{*}{ Cumulative protein intake (g) } & ED & $4.56 \pm 0.1970 \mathrm{~b}$ & $0.0482 \pm 0.0026$ & $42.563 \pm 1.0919$ \\
\hline & $\mathrm{CD}$ & $5.42 \pm 0.5732 \mathrm{a}$ & $0.0485 \pm 0.0023$ & $42.655 \pm 0.9413$ \\
\hline$P$ value & & 0.0001 & 0.7863 & 0.8405 \\
\hline \multirow{2}{*}{ Total body protein (mg) } & $\mathrm{ED}$ & $873.8 \pm 0.1837 \mathrm{a}$ & $0.0478 \pm 0.0122$ & $43.759 \pm 2.3173$ \\
\hline & $\mathrm{CD}$ & $697.0 \pm 0.0373 b$ & $0.0672 \pm 0.0062$ & $41.271 \pm 1.0896$ \\
\hline$P$ value & & 0.0265 & 0.0817 & 0.2525 \\
\hline \multirow{2}{*}{ Total body water (mg) } & $\mathrm{ED}$ & $9.103 .8 \pm 0.8588 \mathrm{a}$ & $0.0564 \pm 0.0088$ & $37.461 \pm 2.2084$ \\
\hline & $\mathrm{CD}$ & $8.168 .8 \pm 0.3603 b$ & $0.0599 \pm 0.0048$ & $36.467 \pm 1.0097$ \\
\hline$P$ value & & 0.0028 & 0.5940 & 0.1574 \\
\hline \multirow{2}{*}{ Total body fat (mg) } & ED & $469.4 \pm 0.0864$ & $0.0568 \pm 0.0154$ & $43.961 \pm 3.9850$ \\
\hline & $\mathrm{CD}$ & $421.5 \pm 0.0330$ & $0.0592 \pm 0.0061$ & $46.103 \pm 1.6829$ \\
\hline$P$ value & & 0.6612 & 0.4787 & 0.1197 \\
\hline \multirow{2}{*}{ Total body ash (mg) } & $\mathrm{ED}$ & $195.6 \pm 0.0444$ & $0.0443 \pm 0.0105$ & $48.064 \pm 2.932$ \\
\hline & $\mathrm{CD}$ & $169.6 \pm 0.0124$ & $0.0528 \pm 0.0043$ & $47.024 \pm 1.706$ \\
\hline$P$ value & & 0.1044 & 0.0545 & 0.7943 \\
\hline
\end{tabular}

$\mathrm{Pm}=$ weight or length at maturity; $\mathrm{b}($ per day $)=$ maturation rate; $t^{*}($ days $)=$ time of maximum growth rate. Means in the same column followed by different superscript letters differ significantly ( $\mathrm{P}<0.05, \mathrm{~F}$ test).

Source: Elaboration of the authors.

\section{Feed intake}

No significant difference in food intake was observed between tadpoles receiving the experimental and commercial diets (Table 3). Estimation of food intake using the Gompertz model provided values similar to those observed (Figure 1D).

\section{Feed conversion}

Tadpoles receiving the experimental diet presented better feed conversion than those fed the commercial diet despite the lower protein content of the former diet $(\mathrm{p}<0.05)$ (Table 4$)$. 
Figure 1. Daily weight gain (A), daily food (B) and protein (C) intake, and daily deposition of protein (D), water (E), fat $(\mathrm{F})$ and ash $(\mathrm{G})$ of bullfrog tadpoles fed the experimental (ED) and commercial (CD) diets.
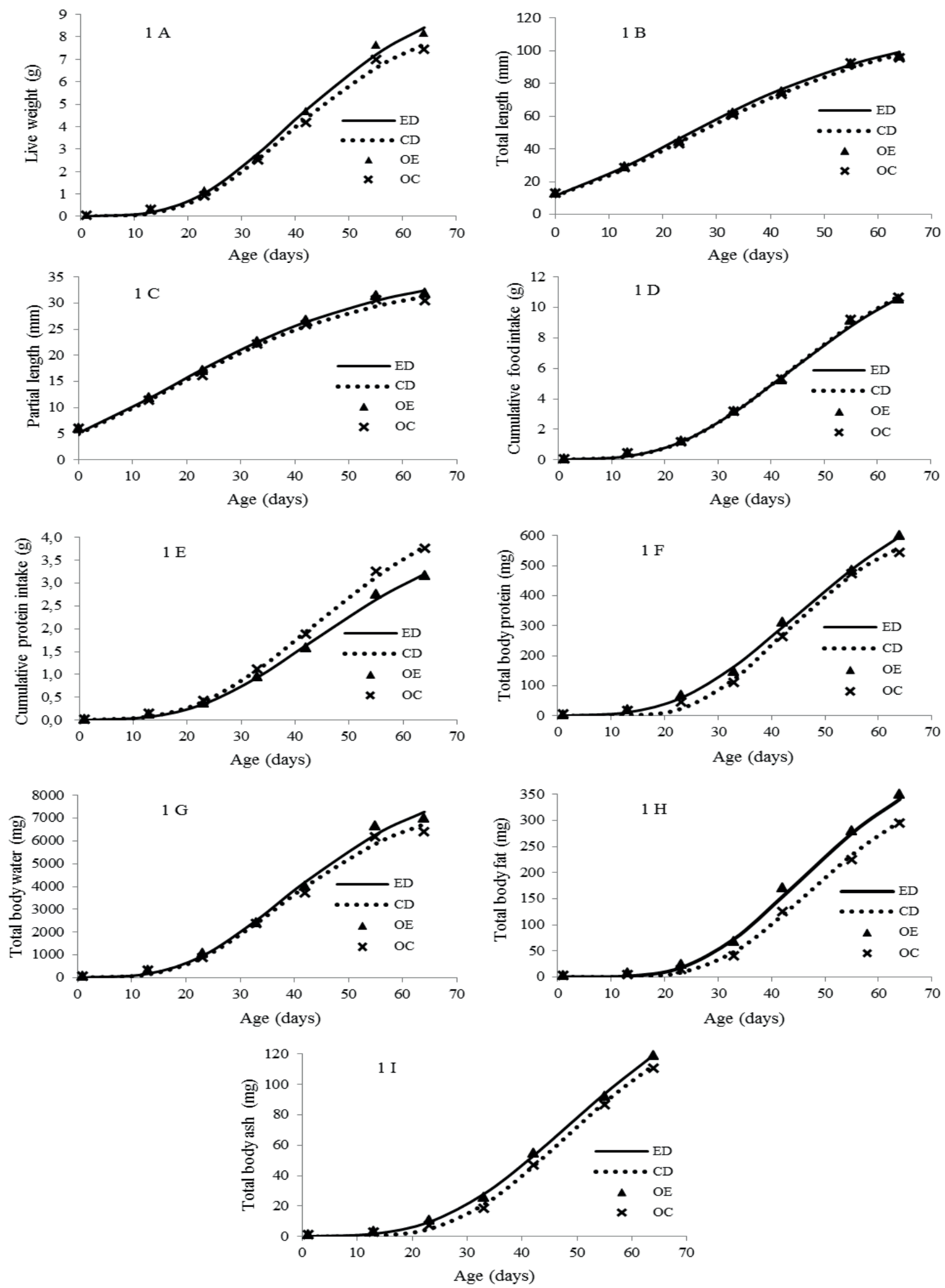

Source: Elaboration of the authors. 
Figure 2. Curve of live weight (A), total length (B), partial length (C), cumulative food (D) and protein (E) intake, total protein $(\mathrm{F})$, total water $(\mathrm{G})$, total fat $(\mathrm{H})$, and total ash (I) obtained for bullfrog tadpoles fed the experimental (ED) and commercial $(\mathrm{CD})$ diets. Observed values for the experimental (OE) and commercial (OC) diets.
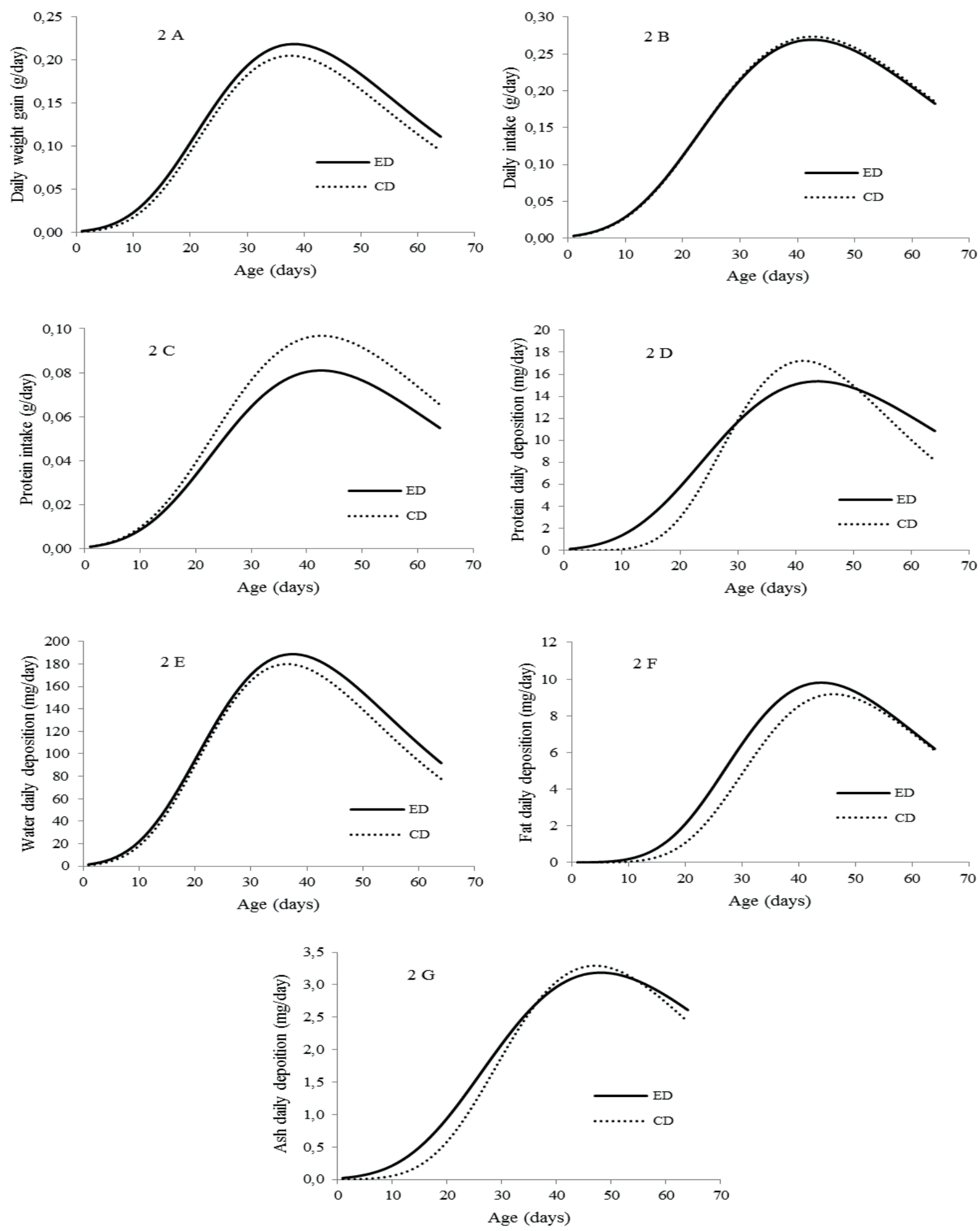

Source: Elaboration of the authors. 
Table 4. Apparent feed conversion observed and estimated by equation of Gompertz, for bullfrog tadpoles fed the experimental and commercial diets.

\begin{tabular}{lcc}
\hline \multirow{2}{*}{ Diet } & \multicolumn{2}{c}{ Mean feed conversion } \\
\cline { 2 - 3 } & Observed & Estimated \\
\hline Experimental & $1.28 \pm 0.07^{\mathrm{a}}$ & $1.26 \pm 0.04^{\mathrm{a}}$ \\
Commercial & $1.43 \pm 0.05^{\mathrm{b}}$ & $1.40 \pm 0.03^{\mathrm{b}}$ \\
\hline
\end{tabular}

Means in the same column followed by different superscript letters differ significantly $(\mathrm{P}<0.05, \mathrm{~F}$ test $)$.

Source: Elaboration of the authors.

\section{Protein intake and carcass nutrient deposition}

Tadpoles fed the commercial diet presented significantly higher protein intake since the diet contained higher amounts of crude protein (Table 3 and Figure 1E). However, daily protein intake rate (b) and time of maximum growth $\left(t^{*}\right)$ were the same for the two diets (Table 3). Although tadpoles receiving the commercial diet had consumed more crude protein, protein deposition was significantly higher in the carcass of animals fed the experimental diet (Table 3 and Figure 1F). This finding indicates that, despite the lower protein content of the experimental diet $(26.23 \%$ digestible protein and $32.68 \%$ crude protein) compared to the commercial diet ( $37.92 \%$ crude protein), the protein of the former was better utilized by the animals, suggesting that it is good quality protein.

On the basis of Figure $1 \mathrm{E}$ and $1 \mathrm{~F}$, a correlation was observed between protein intake and total carcass protein, with protein retention being lower in tadpoles fed the commercial diet (Figure 2D), although these animals had consumed larger daily amounts of protein (Figure 2C). In addition, the sigmoidal model was much more homogenous for tadpoles fed the experimental diet despite higher final protein deposition, indicating more constant daily protein deposition (Figure 2D).

No significant difference in carcass fat deposition was observed between tadpoles fed the different diets (Table 3). The gradual increase in fat deposition was due mainly to the growth of the fat body during tadpole development. As can be seen in Figure 1H, fat deposition in the carcass occurred later than protein and water deposition. Although tadpoles fed the experimental diet presented an increase in daily fat deposition at the beginning of the experiment, no significant difference was observed between groups (Table 3) and the rate was similar at the end of the experiment (Figure 2F).

\section{Discussion}

Physical and chemical characteristics of the water

These values are within the range considered to be optimal for tadpole rearing $\left(24.5\right.$ to $29.1^{\circ} \mathrm{C}$ ) (LIMA; CASALI; AGOSTINHO, 2003; BAMBOZZI et al., 2004; HAYASHI et al., 2004; SEIXAS FILHO et al., 2008). The water temperature interferes directly with the metabolism of the animals since tadpoles are ectotherms, with favorable temperature conditions increasing the growth rate and body weight gain of the animals (HOFFMANN; LEBOUTE; SOUZA, 1989).

The mean dissolved oxygen content of the water $(3.07 \pm 0.92 \mathrm{mg} / \mathrm{L})$ was within the acceptable range proposed by Hailey et al. (2006) for tadpole rearing. The electrical conductivity of the tank water ( $38 \pm$ $0.26 \mu \mathrm{S} / \mathrm{cm}$ ) was within the range recommended by Sipaúba-Tavares (1994) for the culture of aquatic organisms in ponds (23.0 to $71.0 \mu \mathrm{S} / \mathrm{cm})$. The mean $\mathrm{pH}$ of the tank water $(6.17 \pm 0.34)$ was close to the 6.5 reported by Albinati, Lima and Donzele (2001).

The water quality was adequate for tadpole rearing since organic matter deposited at the bottom of the tanks was removed and food supply was controlled to prevent excess residues at the bottom of the tank.

\section{Growth}

Weight at maturity $(\mathrm{Wm})$ is a parameter that expresses genetically the potential of development and the interactions of genes that determine growth, 
with the asymptotic measurement becoming a parameter resulting from previous growth stages (SILVA et al., 2004).

The protein content of this diet differs from the $55 \%$ crude protein reported by CamonaOsalde et al. (1996), 45 and 55\% crude protein used by Seixas Filho et al. (2010), and 36.8\% digestible protein reported by Hayashi et al. (2004). Dietary protein content affects the growth rate of tadpoles and the metamorphic climax can only be achieved when the tadpole fulfills its nutritional requirements, permitting them to transform into a new and completely different animal (CARMONA-OSALDE et al., 1996). This nutritional dependence has also been reported by Martínez, Herráez and Álvarez (1994) for Rana perezi. The authors observed that inadequate feeding prolonged the larval period.

Growth rates are highly flexible when environmental interactions influence the size of the animals, with specific growth and mortality being the fundamental factors that characterize the growth of a population (WERNER; GILLIAM, 1984). It is widely accepted that amphibians and reptiles exhibit indeterminate growth and that body size and age are therefore positively correlated (DUELLMAN; TRUEB, 1994).

The pattern of the tadpole growth curve differs markedly from that of postmetamorphic animals. Tadpoles have a rapid growth rate (MONELLO et al., 2006) and the exponential function of the Gompertz model fits the data well (SOCKMAN et al., 2008). The parametric variables of the model can be generated by various biological processes, such as the supply, distribution and access of the animal to food, variations in feed quality, or animal heterogeneity causing competition, factors that interfere with the growth curve and deposition of nutrients (HOTA, 1994).

\section{Feed intake}

Figure 2B illustrates the daily food intake of bullfrog tadpoles. A marked decline in food intake was observed after day 42 as a result of the onset of metamorphic climax. This phase is especially stressful for tadpoles and is characterized by complex anatomophysiological modifications (WRIGHT; RICHARDSON; BIGOS, 2011), including the change from omnivorous to carnivorous feeding habits. During this stage, the tadpole stops eating and feeds on body fat and tail reserves (OLIVEIRABAHIA, 2007).

\section{Feed conversion}

This finding demonstrates that the experimental diet is better for tadpoles as indicated by the higher weight gain of these animals. Since tadpoles are omnivores (OLIVEIRA-BAHIA, 2007), highprotein diets are not required for better development.

The present results indicate clear improvement of productivity when compared to the data reported by Lima and Agostinho (1992) and Lima, Casali and Agostinho (2003) (mean feed conversion ratio of 1.5), with the experimental diet providing a mean feed conversion ratio of 1.28 . These results may contribute to a reduction in production costs, which correspond to $57 \%$ of total costs of frog feeding (LIMA; AGOSTINHO, 1992).

\section{Protein intake and carcass nutrient deposition}

According to Reginatto et al. (2000), the higher and longer the plateau of protein deposition in an animal, the more efficient is the meat production and the better its body composition. Tadpole metamorphosis should not occur before the animals have stored a minimum amount of energy. Under conditions of high tadpole density, the animals are likely to spend more energy to prevent physical 
encounters and other associated stresses. In addition, less energy is probably stored if reserves are necessary to combat growth inhibitors under conditions of high density, for example, in intensive commercial tadpole culture systems (GRUMP, 1981). Even if there is a superabundance of food, competition is expected and a balanced diet is therefore necessary to meet the nutritional needs of tadpoles (MARTÍNEZ; ÁLVAREZ; HERRÁEZ, 1996).

Diets elaborated for animal feeding should contain a balance of protein and energy so that the animal grows without converting excess protein into energy or depositing large amounts of adipose tissue in the carcass (ALBINATI et al., 2001). However, protein and energy sources represent the largest cost of diet production and any imbalance can lead to economic losses.

The deposition rate of body water is intimately related to the rate of body protein deposition (REGINATTO et al., 2000), demonstrating that tadpoles start to retain more water during this period as a result of higher protein synthesis. Water deposition was significantly higher in tadpoles fed the experimental diet (Table 3 and Figure 1G), a finding that is directly related to the higher protein deposition observed in this group.

An association between water and fat deposition rates was observed at the time when deposition of the two nutrients declined (Figure 2E and 2F), in agreement with the findings of Silva; Albino and Nascimento (2003). The decline in water deposition was much more critical, i.e., the animal deposits more fat than water during the final phase, showing that the higher the quantity of body water, the less fat the animal will present.

Maximum ash deposition was the last to occur when compared to the other nutrients, with no significant difference in carcass ash deposition between tadpoles fed the two diets (Table 3). This finding demonstrates similar bone formation in the two groups (Figures $2 \mathrm{G}$ and $1 \mathrm{I}$ ) and synchronous growth. Muscle tissue growth occurs before adipose tissue growth which, in turn, is more accelerated than bone tissue growth since in tadpoles the hind limbs and forelimbs develop during the final stage of metamorphosis. As a consequence, the highest mineral deposition in bone tissue is observed at the end of growth (GARTNER; HIATT, 2007).

\section{Conclusion}

The Gompertz model provided a good fit of the data to describe the morphometric growth curve and carcass nutrient deposition of bullfrog tadpoles. A higher growth rate and nutrient deposition were observed for tadpoles receiving the experimental $\operatorname{diet}(26.23 \%$ digestible protein).

\section{Acknowledgements}

We thank the state funding agency Fundação de Amparo à Pesquisa do Estado de São Paulo (FAPESP) for financial support.

\section{References}

AGOSTINHO, C. A.; SILVA, M. A.; TORRES, R. A.; LIMA, S. L. Curvas de crescimento de rãs-pimenta, Leptodactyllus labyrinthicus (Spix, 1824). Revista Brasileira de Zootecnia, Viçosa, v. 20, n. 3, p. 47-54, 1991.

ALBINATI, R. C. B.; LIMA, S. L.; DONZELE, J. L. Níveis de energia digestível na ração de girinos de rãtouro. Revista Brasileira de Saúde e Produção Animal, Salvador, v. 2, n. 1, p. 48-52, 2001.

ALBINATI, R. C. B.; LIMA, S. L.; TAFURI, M. L.; DONZELE, J. L. Digestibilidade aparente de dois alimentos protéicos e três energéticos para girinos de rãtouro (Rana catesbeiana, Shaw, 1802). Revista Brasileira de Zootecnia, Viçosa, v. 29, n. 2, p. 2151-2156, 2000.

BAMBOZZI, C. A.; SEIXAS FILHO, J. T.; THOMAZ, L. A.; OSHIRO, M. Y. Efeito do fotoperíodo sobre o desenvolvimento de girinos de rã-touro (Rana catesbeiana Shaw, 1802). Revista Brasileira de Zootecnia, Viçosa, v. 33, n. 4, p. 1-17, 2004.

BARBOSA, J. M.; SILVEIRA, A. M.; GOMIDE, C. A. Crescimento heterogêneo de girinos de rã- 
touro alimentados com diferentes rações. Pesquisa Agropecuária Brasileira, Brasília, v. 40, n. 3, p. 10151019, 2005.

CARMONA-OSALDE, C.; OLVERA-NOVOA, M. A.; RODRIGUEZ-SERNA, M.; FLORES-NAVA, A. Estimation of the protein requirement for bullfrog (Rana catesbeiana) tadpoles, and its effect on metamorphosis ratio. Aquaculture, Amsterdam, v. 141, n. 1-4, p. 223231, 1996.

DUELLMAN, W. E.; TRUEB, L. Biology of amphibians. Baltimore: The Johns Hopkins University Press, 1994. $670 \mathrm{p}$.

ETHERIDGE, R. D.; PESTI, G. M.; FOSTER, E. H. A comparison of nitrogen values obtained utilizing the Kjeldahl nitrogen and Dumas combustion methodologies (Leco CNS 2000) on samples typical of an animal nutrition analytical laboratory. Animal Feed Science and Technology, Amsterdam, v. 73, n. 1-2, 73, p. 21-28, 1998.

GARTNER, L. P.; HIATT, J. L. Tratado de histologia em cores. 3. ed. Rio de Janeiro: Elsevier, 2007. 436 p.

GOSNER, K. L. A. Simplified table for staging anuran embryos and larvae with notes on identification. Herpetologica, Emporia, v. 16, n. 1-2, p. 183-190, 1960.

GRUMP, M. L. Energy accumulation and amphibian metamorphosis. Oecologia, New York, v. 49, n. 2, p. 167169, 1981.

HAILEY, A.; SOOKOO, N.; MOHAMMED, A.; KHAN, A. Factors affecting tadpole growth: development of a rearing system for the Neotropical Leptodactylid Physalaemus pustulosus for ecotoxicological studies. Applied herpetology, Leiden, v. 3, n. 2, p. 111-128, 2006.

HARTLEY, H. O. The modified gauss newton method for the fitting of non-linear regression functions by least squares. Thechnometrics, Alexandria,v. 3, n. 2, p. 269280, 1961.

HAYASHI, C.; SOARES, C. M.; GALDIOLI, E. M.; FURUYA, V. R. B.; BOSCOLO, W. R. Desenvolvimento de girinos de rã-touro (Rana catesbeiana Shaw, 1802) cultivados em diferentes densidades de estocagem em tanque-rede. Revista Brasileira de Zootecnia, Viçosa, v. 33, n. 1, p. 14-20, 2004.

HOFFMANN, D. F.; LEBOUTE, E. M.; SOUZA, S. M. G. Efeito da temperatura e desenvolvimento de girinos de rã-touro (Rana catesbeiana Shaw, 1802). Revista Brasileira de Zootecnia, Viçosa, v. 18, n. 3, p. 557-566, 1989.

HOTA, A. K. Growth in amphibians. Gerontology, Basel, v. 40, n. 2, p. 147-160, 1994.
LIMA, S. L.; AGOSTINHO, C. A. A tecnologia de criação de rãs. Viçosa: UFV, 1992. 168 p.

LiMA, S. L.; CASAli, A. P.; AgOSTINHO, C. A. Desempenho zootécnico e tabela de alimentação de girinos de rã-touro (Rana catesbeiana) criados no sistema anfigranja. Revista Brasileira de Zootecnia, Viçosa, v. 32, n. 4, p. 512-518, 2003.

MANSANO, C. F. M.; DE STÉFANI, M. V.; PEREIRA, M. M.; MACENTE, B. I. Non-linear growth models for bullfrog tadpoles. Ciência e Agrotecnologia, Lavras, v. 36, n. 4, p. 454-462, 2012.

MARCATO, S. M.; SAKOMURA, N. K.; FERNANDES, J. B. K.; SIQUEIRA, J. C.; DOURADO, L. R. B.; FREITAS, E. R. Crescimento e deposição de nutrientes nos órgãos de frangos de corte de duas linhagens comerciais. Revista Brasileira de Zootecnia, Viçosa, v. 39, n. 4, p. 1082-1091, 2010.

MARCATO, S. M.; SAKOMURA, N. K.; MUNARI, D. P.; FERNANDES, J. B. K.; KAWAUCHI, I. M.; BONATO, M. A. Growth and body nutrient deposition of two broiler commercial genetic lines. Brazilian Journal of Poultry Science, Campinas, v. 10, n. 4, p. 117-123, 2008.

MARTÍNEZ, I. P.; ÁlVAREZ, R.; HERRÁEZ, M. P. Growth and metamorphosis of Rana perezi in culture: effects of larval density. Aquaculture, Amsterdam, v. 142, n. 1-4, p. 163-170, 1996.

MARTÍNEZ, I. P.; HERRÁEZ, M. P.; ÁLVAREZ, R. Response of hatchery-reared Rana perezi larvae fed different diets. Aquaculture, Amsterdam, v. 128, n. 6-12, p. 235-244, 1994.

MONELLO, R. J.; DENNEHY, J. J.; MURRAY, D. L.; WIRSING, A. J. Growth and behavioral responses of tadpoles of two native frogs to an exotic competitor, Rana catesbeiana. Journal of Herpetology, Laclede, v. 40, n. 1, p. 403-407, 2006.

OLIVEIRA-BAHIA, V. R. L. Morfologia e enzimologia do sistema digestorio dos girinos da ra-touro (Rana catesbeiana) durante o desenvolvimento e metamorfose. 2007. Tese (Doutorado em Aquicultura) - Centro de Aqüicultura, Universidade Estadual Paulista, Jaboticabal.

REGINATTO, M. F.; RIBEIRO, A. M. L.; OENZ JUNIOR, A. M.; KESSLER, A. M.; KRABBER, E. L. Efeito da energia, relação energia: proteína e fase de crescimento sobre o desempenho e composição de carcaça de frangos de corte. Revista Brasileira de Ciência Avicolas, Campinas, v. 2, n. 3, p. 107-133, 2000.

ROBERTS, A.; FEETHAM, B.; PAJAK, M.; TEARE, T. Responses of hatchling Xenopus tadpoles to water 
currents: first function of lateral line receptors without cupulae. Journal of Experimental Biology, Cambrigde, v. 212, n. 1, p. 914-921, 2009.

RODRIGUES, M. L.; LIMA, S. L.; MOURA, O. M.; AGOSTINHO, C. A.; SILVA, J. H. V.; CRUZ, G. R. B.; CAMPOS, V. M.; CASALI, A. P.; MENDES, R. R. B.; ALBUQUERQUE, A. G. Curva de crescimento em rãtouro na fase de recria. Archivos de Zootecnia, Cordoba, v. 56, n. 5, p. 125-136, 2007.

SANTOS, V. B.; FREITAS, R. T. F.; SILVA, F. F.; FREATO, T. A. Avaliação de curvas de crescimento morfométrico de linhagens de tilápia do nilo (Oreochromis niloticus). Ciência e Agrotecnologia, Lavras, v. 31, n. 2, p. 1486-1492, 2007.

SARMENTO, J. L. R.; REZAZZI, A. J.; SOUZA, W. H.; TORRES, R. A.; BREDA, F. C.; MENEZES, G. R. O. Estudo da curva de crescimento de ovinos Santa Inês. Revista Brasileira de Zootecnia, Viçosa, v. 35, n. 6, p. 435-442, 2006.

SCHMIDT, B. P.; KNOWLES, J. M.; SIMMONS, A. M. Movements of Rana catesbeiana tadpoles in weak current flows resemble a directed random walk. Journal of Experimental Biology, Cambrigde, v. 214, n. 3, p. 2297-2307, 2011.

SECCO, E. M.; STÉFANI, M. V.; VIDOTTI, R. M. Apparent digestibility of different ingredients in diets for bullfrog Rana catesbiana tadpoles. Journal of the World Aquaculture Society, Baton Rouge, v. 36, n. 1, p. 135140, 2005.

SEIXAS FILHO, J. T.; HIPOLITO, M.; CARVALHO, V. F.; MARTINS, A. M. C. R. P. F.; SILVA, L. N.; CASTAGNA, A. A. Alterações histopatológicas em girinos de rã-touro alimentados com rações comerciais de diferentes níveis protéicos. Revista Brasileira de Zootecnia, Viçosa, v. 37, n. 4, p. 2085-2089, 2008.

SEIXAS FILHO, J. T.; MELO, S. C. R. P.; SILVA, J. M. F.; TOMAS, J. E.; MELO, C. M. S. Efeito de níveis de energia e proteína bruta no desempenho de girinos (Rana catesbeiana, Shaw, 1802). Revista Brasileira de Zootecnia, Viçosa, v. 27, n. 2, p. 664-669, 1998.

SEIXAS FILHO, J. T.; NAVARRO, R. D.; SILVA, L. N.; GARCIA, S. L. R.; HIPÓLITO, M. Desempenho de girinos de rã-touro alimentados com ração comercial contendo diferentes concentrações de proteína bruta. Revista Brasileira de Ciências Agrárias, Recife, v. 5, n. 3, p. 428-433, 2010.

SILVA, D. J.; QUEIROZ, A. C. Análise de alimentos: métodos químicos e biológicos. 3. ed. Viçosa, MG: Editora UFV, 2002. 235 p.
SILVA, F. L.; ALENCAR, M. M.; FREITAS, A. R.; PACKE, I. U.; MOURÃO, G. B. Curvas de crescimento em vacas de corte de diferentes tipos biológicos. Pesquisa Agropecuária Brasileira, Brasília, v. 46, n. 4, p. 262-271, 2011.

SILVA, J. H. V. D.; ALBINO, L. F. T.; NASCIMENTO, A. H. D. Estimativas da composição anatômica da carcaça de frangos de corte com base no nível de proteína da ração e peso da carcaça. Revista Brasileira de Zootecnia, Viçosa, v. 32, n. 1, p. 344-352, 2003.

SILVA, N. A. M.; AQUINO, L. H.; SILVA, F. F.; OLIVEIRA, A. I. G. Curvas de crescimento e influência de fatores não-genéticos sobre as taxas de crescimento de bovinos da raça Nelore. Ciência e Agrotecnologia, Lavras, v. 28, n. 2, p. 647-654, 2004.

SIMMONS, A. M.; COSTA, L. M.; GERSTEIN, H. B. Lateral line-mediated rheotactic behavior in tadpoles of the African clawed frog (Xenopus laevis). Journal Comparative Physiology Part A, New York, v. 190, n. 9, p. 747-758, 2004.

SIPAÚBA-TAVARES, L. H. Limnologia aplicada à aquicultura. Jaboticabal: FUNEP, 1994. 70 p.

SOCKMAN, K. W.; WEISS, J.; WEBSTER, M. S.; TALBOTT, V.; SCHWABL, H. Sex-specific effects of yolk-androgens on growth of nestling American kestrels. Behavioral Ecology and Sociobiology, New York, v. 62, n. 4, p. 617-625, 2008.

SOLOMON, R. J.; TARUWA, S. M. The Growth comparison of two catfishes (C. Gariepinus and Heteroclarias), Nature and Science, New York, v. 9, n. 8, p. 138-148, 2011.

STATISTICAL ANALYSES SYSTEM - SAS. Version release 8.2. for windows. 2001. CD-ROM.

WAFA, A. H.; PIERRE, D.; DANIEL, B. Modelling growth and food intake rhythms of brook trout Salvelinus fontinalis under the effects of density and ration. Ecological Modelling, Amsterdam, v. 175, n. 4, p. 385394, 2004.

WERNER, E. E.; GILLIAM, J. F. The ontogenetic niche and species interactions in size- structured populations. Annual Review of Ecology and Systematics, Palo Alto, v. 15, n. 2, p. 393-425, 1984.

WINSOR, C. P. The Gompertz curve as a growth curve. Proceedings of the National Academy of Sciences of the United States of America, Washington, v. 18, n. 1, p. 1-8, 1932.

WRIGHT, M. L.; RICHARDSON, S. E.; BIGOS, J. M. The fat body of bullfrog (Lithobates catesbeianus) 
tadpoles during metamorphosis: chages in mass, histology and melatonin content and effect of food deprivation. Comparative Biochemistry and Physiology

Part A, Oxford, v. 160, n. 1, p. 498-503, 2011. 